\title{
FAKTOR PERMASALAHAN PENDEKATAN SAINTIFIK 5M DALAM PEMBELAJARAN MATEMATIKA DI SMA
}

\section{(THE PROBLEM FACTOR OF THE 5M SCIENTIFIC APPROCH IN LEARNING MATHEMATICS IN HIGH SCHOOL)}

\author{
Elly Anjarsari ${ }^{1}$ \\ 1Universitas Islam Lamongan, ellyanjar@yahoo.com
}

\begin{abstract}
Abstrak. Dalam proses belajar mengajar di sekolah, ada saja kendala yang dialami setiap guru selama proses KBM berlangsung. Tujuan tulisan ini adalah meneliti dan menganalisis bagaimana implementasi pendekatan saintifik pada pembelajaran matematika, serta menganalisis permasalahan yang terjadi dalam pendekatan saintifik. Sumber subjek penelitian ini adalah para siswa dan guru sekolah SMA Sugihwaras. Teknik pengambilan sample yang digunakan adalah purposive sampling dan snowball sampling. Teknik pengumpulan data yang digunakan adalah observasi, wawancara, dan dokumentasi. Uji keabsahan data dalam penelitian ini menggunakan triangulasi sumber, metode, dan teori. Berdasarkan hasil analisis data disimpulkan bahwa: (1) masih belum sepenuhya menerapkan pendekataan saintifik dalam pembelajaran matematika (2) belum berubah sepenuhnya paradigma guru mengenai kurikulum baru dengan kurikulum sebelumnya.
\end{abstract}

Kata Kunci: Kurikulum 2013, pembelajaran matematika, pendekatan saintifik

\begin{abstract}
In the teaching and learning process in schools, there are only obstacles that each teacher experiences during the learning process. The purpose of this paper is to examine and analyze how the implementation of the scientific approach to learning mathematics, and analyze the problems that occur in the scientific approach. The source of this research subject was Sugihwaras High School students and teachers. The sampling technique used was purposive sampling and snowball sampling. Data collection techniques used were observation, interviews, and documentation. The validity test of the data in this study uses triangulation of sources, methods, and theories. Based on the results of the data analysis, it was concluded that: (1) the implementation of scientific approaches in mathematics learning was not fully (2) the teacher paradigm had not changed completely about the new curriculum with the previous curriculum.
\end{abstract}

Keywoards: 2013 curriculum, mathematics learning, scientific approach 


\section{PENDAHULUAN}

Reformasi Pendidikan di Indonesia perlu adanya mempertimbangkan tujuan, kurikulum, sumber daya, pembelajaran, pengajaran, dan penilaian. Keberhasilan reformasi ini menunjukkan seberapa baik aspek yang dibuat. Kurikulum dan pembelajaran merupakan kesatuan yang saling berkaitan. Kurikulum sekolah harus dirancang agar siswa mampu menggunakan ketrampilan dan kemampuan dalam memecahkan masalah nyata kemudian siswa mampu mengkomunikasikan. Dengan adanya kurikulum maka terbentuklah perencanaan yang menyediakan kesempatan siswa untuk belajar.

Sebelumnya di Indonesia menerapkan KTSP (Kurikulum Tingkat Satuan Pendidikan) yang mana saat ini sudah berkembang dan berubah menjadi kurikulum 2013. Kurikulum ini mempunyai tujuan untuk membentuk para generasi Indonesia agar memiliki ketrampilan dan kemampuan sebagai pribadi yang memiliki iman akan keyakinan, produktif, inovatif, dan kreatif serta berguna untuk kehidupan di lingkungan dan peradaban dunia.

Kurikulum 2013 terdapat dua proses pembelajaran, yaitu dengan pembelajaran langsung (direct instruction) dan pembelajaran tidak langsung (indirect instruction). Proses pembelajaran langsung merupakan proses kegiatan dimana siswa dituntun untuk mengembangkan ilmu pengetahuan, kemampuan dalam berpikir, serta ketrampilan psikomotorik dengan cara berinteraksi langsung menggunakan sumber belajar yang sudah dirancang dalam silabus maupun rencana perangkat pembelajaran (RPP). Proses kegiatan tersebut siswa mengamati, menanya, mengumpulkan informasi, menganalisis, serta mengkomunikasikan apa yang sudah ditemukan dalam kegiatan tersebut. Sedangkan proses pembelajaran tidak langsung adalah proses pembelajaran yang berkaitan dengan pengembangan nilai dan sikap. Model yang digunakan bersifat multiarah. Peran guru beralih dari penceramah menjadi fasilitator dan pendukung. Kelebihan pembelajaran ini salah satunya mendorong ketertarikan dan kaingintahuan siswa serta menciptakan alternatif pertanyaan beserta solusinya.

Terdapat pendekatan yang digunakan dalam kurikulum 2013, yaitu pendekatan saintifik (Scientific approach). Pembelajaran dengan pendekatan saintifik adalah proses pembelajaran yang dirancang sedemikian rupa agar peserta didik secara aktif mengkonstruksi konsep, hukum, atau prinsip melalui tahapan-tahapan mengamati, merumuskan masalah, mengajukan hipotesis, mengumpulkan data, menganalisis data, menarik kesimpulan dan mengkomunikasikan konsep, hukum, atau prinsip yang ditemukan. (Kurinarsih, 2014.29) pendekatan saintifik dimaksudkan agar siswa mengenal, memahami, dan membangun pengetahuan dengan kegiatan ilmiah. Pernyataan tersebut selaras dengan pendapat hosnan (2014:34) bahwa pembelajaran dalam kurikulum 2013 mengarahkan siswa untuk mencari tahu melalui observasi dan bukan 
diberi tahu. Siswa sepertinya akan selalu dihadapkan sesuatu yang baru dalam suatu kegiatan. Sehingga dalam pembelajaran saintifik ini, peran guru diharapkan mampu membimbing siswa untuk menyelesaikan ketrampilan kegiatan dalam pembelajaran.

Pembelajaran yang digunakan kebanyakan masih menggunakan pembelajaran konvensional. Padahal disini yang dibutuhkan adalah kompetensi guru yang memadai sehingga guru mampu merubah kebiasaan mengajar dengan cara yang lama ke pembelajaran yang lebih mengutamakan keaktifan siswa. Bahkan membuat siswa tidak bisa membentuk suatu konsep sendiri, karna masih memakai gaya mengajar yang lama. Metode yang digunakan adalah metode ceramah. Pada penelitian ini, peneliti lebih focus meneliti bagaimana implementasi pendekatan saintifik pada pembelajaran matematika, dan menganalisis permasalahan apa saja yang ada selama proses kegiatan pembelajaran matematika dengan pendekatan saintifik pada kurikulum sekarang ini di tingkat SMA yang ada di Tuban. Diharapkan penelitian ini dijadikan perbaikan dalam mengambil kebijakan yang akan datang.

\section{METODE PENELITIAN}

Metode yang digunakan dalam penelitian ini adalah penelitian kualitatif. Metode penelitian kualitatif adalah metode penelitian yang berlandaskan pada filsafat postpositivisme, digunakan untuk meneliti pada kondisi obyek yang alamiah (sebagai lawannya adalah eksperimen) dimana peneliti adalah sebagai instrument kunci, pengambilan sampel sumber data dilakukan secara purposive dan snowball, Teknik pengumpulan data dengan trianggulasi (gabungan), analisis data bersifat induktif/kualitatif, dan hasil penelitian kualitatif lebih menekankan makna dari pada generalisasi (Sugiyono, 2014:1).

Metode penelitian kualitatif mempunyai tujuan untuk menemukan teori, menggambarkan realitas yang kompleks, serta memperoleh pemahaman makna. Analisis dilakukan secara terus menerus sejak awal sampai selesai penelitian. Penulis menggunakan metode penelitian kualitatif dengan pendekatan studi kasus. Akan dilakukan penelitian lebih dalam mengenai permasalahan yang ada selama proses pembelajaran dengan pendekatan saintifik pada kurikulum 2013 di SMA Sugihwaras.

\section{A. Teknik mengumpulkan data}

Teknik yang digunakan dalam mengumpulkan data adalah observasi, wawancara, dan dokumentasi. Observasi adalah dasar semua ilmu pengetahuan. Para peneliti hanya dapat bekerja berdasarkan data yang diperoleh melalui observasi. Data itu dikumpulkan dan sering dengan bantuan berbagai alat yang sangat canggih, sehingga benda-benda yang sangat kecil (proton dan elektron) maupun yang sangat jauh (benda ruang angkasa) dapat diobservasi dengan jelas (Nasution, 1998 dalam Sugiyono, 2014:64). 
Peneliti melakukan observasi untuk menyajikan gambaran nyata kejadian, untuk bisa menjawab pertanyaan, membantu mengenali atau mengerti perilaku manusia, serta mengevaluasi terhadap aspek tertentu dan melakukan umpan balik terhadap pengukuran tersebut. Beberapa bentuk observasi yang dapat digunakan dalam penelitian kualitatif, yaitu observasi partisipasi, observasi tidak terstruktur, dan observasi kelompok tidak terstruktur (Bungin, 2007:115). Peneliti menggunakan observasi partisipasi dalam mengumpulkan data melalui pengamatan dimana observer benar benar terlibat dalam keseharian responden. Yang menjadi objek dalam penelitian ini adalah kegiatan proses pembelajaran d kelas, apakah sudah memenuhi teori-teori pembelajaran berbasis pendekatan saintifik, peneliti menggunakan instrumen pedoman observasi terfokus.

Wawancara merupakan suatu pembuktian terhadap informasi yang sudah diperoleh. Proses memperoleh keterangan untuk tujuan penelitian dengan cara tanya jawab sambal bertatap muka antara pewawancara dengan informan. Wawancara dilakukan kepada guru dan siswa sebagai informan.

Dokumentasi merupakan salah satu metode pengumpulan data kualitatif dengan cara melihat atau menganalisis dokumen-dokumen yang dibuat oleh subjk sendiri atau orang lain tentang subjek. Sifatnya tak terbatas waktu sehingga memberikan peluang untuk peneliti lain mengetahui hal-hal yang sudah pernah terjadi. Yang digunakan peneliti adalah dokumen berbentuk foto pada saat observasi di kelas dan wawancara.

\section{B. Instrumen Penelitian}

Yang mempengaruhi kualitas penelitian adalah kualitas instrument penelitian dan kualitas pengumpulan data. Dalam penelitian ini yang menjadi instrument atau alat penelitian adalah peneliti itu sendiri. Peneliti kualitati sebagai human instrument, berfungsi menetapkan focus penelitian, memilih informan sebagai sumber data, melakukan pengumpuln data, menilai kualitas data, analisis data, menafsirkan data dan membuat kesimpulan atas temuanya. Peneliti itu sendiri sebagai alat satu-satunya yang dapat mencapainya. Setelah fokus penelitian menjadi jelas, selanjutnya mengembangkan instrument penelitian sederhana yang dapat melengkapi data.

\section{Teknik Analisis Data}

Analisis telah mulai sejak merumuskan dan menjelaskan masalah, sebelum terjun ke lapangan, dan berlangsung sampai penulisan hasil penelitian. Analisis menjadi pegangan bagi penelitian selanjutnya sampai jika mungkin, teori grounded (Nasution 1998 dalam Sugiyono 2014:336). Dalam kenyataannya, analisis data kualitatif berlangsung selama proses pengumpulan data. Langkah-langkah interaktif yang dilakukan dalam 
proses menganalisis data terdiri dari data reduction, data display, dan conclusion drawing/verification.

1. Data Reduction (Reduksi Data)

Perlu mencatat secara teliti dan rinci karena data yang diperoleh dilapangan cukup banyak. Dengan cara merangkum, dan memilih hal-hal pokok atau penting, serta membuang sesuatu yang tidak perlu. Sehingga akan memperjelas gambaran dan dapat memoermudah peneliti dalam melakukan pengumpulan data selanjutnya. Bagi peneliti baru, dapat didiskusikan dengan teman dalam mereduksi data sehingga wawasan peneliti berkembang.

2. Data Display (Penyajian Data)

Langkah berikutnya setelah direduksi adalah mendisplaykan data atau menyajikan data. Penyajian data dalam kualitatif dapat berbentuk uraian naratif, bagan, table, grafik, hubungan antar kategori, dan sejenisnya.

3. Conclusion Drawing/Verification

Langkah ketiga dalam analisis data kualitatif adalah penarikan kesimpulan dan verifikasi. Kesimpulan dalam penelitian kualitatif mungkin dapat menjawab rumusan masalah mungkin juga tidak bisa. Namun, jika kesimpulan yang dikemukakan pada tahap awal didukung oleh bukti bukti yang valid dan konsisten saat peneliti mengumpulkan data, maka kesimpulan yang dikemukakan adalah kesimpulan yang kredibel.

Dalam penelitian ini, data tentang perencanaan pembelajaran, pelaksanaan pembelajaran, dan hambatan ynag ditemui dalam kurikulum 2013 serta upaya yang dilakukan guru di kelas untuk mengatasinya, telah tertulis dalam penyajian data, kemudian dianlisis untuk memperoleh kesimpulan.

\section{HASIL DAN PEMBAHASAN}

\section{A. Analisis Data}

Triangulasi adalah teknik pemeriksaan keabshan data yang memanfaatkan sesuatu yang lain. Di luar data itu untuk keperluan pengecekan atau sebagai pembanding terhadap dta itu (Moleong, 2012:330). Tringulasi yang digunakan adalah triangulasi sumber, triangulasi metode, dan triangulasi teori.

a. Triangulasi Sumber

Dari hasil wawancara dengna peserta didik, Kurikulum yang sedang berjalan di SMAN 1 Sugihwaras kelas 12 adalah kurikulum 2013. Sebelumnya peserta didik pernah mendapatkan sosialisasi tentang Kurikulum 2013. Sebagian besar dari mereka sudah paham mengenai Kurikulum 2013. Meskipun pendekatan ini belum bisa diterapkan sepenuhnya, akan tetapi sekarang pendekataan saintifik sudah mulai diterapkan dalam pembelajaran maatematika. Terkadang para pesertaa didik masih malu dalam hal bertanya 
ketika mereka mendapat kesulitan dan memilih bertanya kepada teman atau kakak kelasnya. Mereka masih merasa kurang percaya diri dalam berkomunikasi.

b. Triangulasi Metode

Dari hasil observasi di dalam kelas, guru belum sepenuhya menyampaikan tujuan pembelajaran. Akan tetapi guru menyampaikan kegiatan pembelajaran yang akan dilaksanakan. Guru memberikan motivasi sesui dengan data kegiatan yang ada di RPP. Dari data hasil wawancara dengan salah satu guru matematika yang berada di sekolah tersebut, guru mengakui RPP didapat dari MGMP dan sudah pernah mengikuti pelatihan Kurikulum 2013. Terkadang masih ada saja guru yang hanya fokus terhadap peserta didik dalam mengajar tanpa memperhatikan RPP yang sudah dibuat. Agar proses belajar bisa terarah dengan baik, dan tujuan yang mencakup seluruh aspek bisa dicapai, guru seharusnya melaksanakan pembelajaran sesuai dengan RPP. Pembelajaran matematika belum sepenuhnya menggunakan pembelajaran berbasis pendekatan saintifik. Peserta didik masih kesulitan menangkap maksud soal yang menggunakan HOTS, sehingga guru masih perlu melakukan cara mengajar didepan kelas (konvesional) untuk membuat para peserta didik memahami soal tersebut. Selain itu guru terkadang memilih menggunakan metode ceramah karena daya tangkap pemahaman peserta didik terhadap materi masih kurang. Peserta didik belum bisa sendiri, masih butuh banyak dibimbing, misalny adlam kegiatan diskusi. Sehingga dari hasil wawancara yaitu guru sudah mulai menerapkan pendekatan saintifik, akan tetapi masih belum bisa menerapkan pendekatan tersebut untuk setiap pertemuan karena terkendala waktu.

c. Triangulasi Teori

Menurut data hasil observasi dan wawancara, masih ada saja guru yang belum sepenuhnya memperhatikan RPP. Dalam pembelajaran guru belum menjadikan RPP sebagai acuan proses kegiatan pembelajaran. Guru masih fokus terhadap bagaimana agar peserta didik mampu memahami materi yang disampaikan.

$R P P$ adalah rencana penggambaran prosedur dan manajemen pengajaran untuk mencapai satu atau lebih kompetensi dasar yang ditetapkan dalam standart kompetensidna dijabarkan dalm silabus (Mulyasa, 2007:183). Sedangkan RPP (Hosnan, 2014:99) adalah rencana kegiataan pembelajaran tatap muka untuk satu pertemuan atau lebih. RPP dikembangkan dari silabus untuk mengarahkan kegiatan pembelajaran peserta didik dalam upaya mencapai Kompetensi Dasar (KD). Setiap pendidik pada satuan pendidikan berkewajiban menyusun RPP secara lengkap dan sistematis agar pembelajaran berlangsung secara interktif, inspiratif, menyenangkan, menantang, efisien, memotivasi peserta didik untuk berpartisipasi aktif, serta memberikan ruang yang cukup bagi prakaarsa, kreativitas, dan 
kemandirian sesui dengan bakat, minat, dan perkembangan fisik serta psikologis peserta didik.

\section{B. Pembahasan}

Berdasarkan hasil observasi pembelajaran matematika, kemudian dilakukan pembahasan tentang pembelajaran matematika berbasis pendekataan saintifik pada kurikulum 2013. Kurikulum yang sedang dijalankan di SMA Sugihwaras adalah kurikulum 2013. Sudah diadakan sosialisasi bagi peserta didik tentang kurikulum 2013 dan hampir 98\% guru di SMA Sugihwaras telah mengikuti pelatihan kurikulum 2013.

Dalam proses kegiatan pembelajaran guru menggunakan pendekatan saintifik 5M, yaitu mengamati, menanya, menalar, mencoba, dan mengkomunikasikan. Pada pendekatan ini, guru hanya sebagai faasilitator dan membimbing peserta didik untuk menemukan informasi. Pada pendekatan ini guru tidaklah seharusnya menggunakan metode pembelajaran konvensiaonal.

Meskipun belum sepenuhnya menggunakan pendekatan saintifik ini pada setiap pertemuan, akan tetapi di SMA Sugihwaras khususnya pada pembelajaran matematika sudah menerapkan pendekatan tersebut meski belum mutlak. Dikarenakan waktu yang sangat terbatas dan materi pada kurikulum 2013 bertambah banyak dari sebelumnya.

Ketika peserta didik mengkomunikasikan hasil belajar, masih terdapat siswa yang sibuk sendiri, terlihat beberapa peserta didik yang kurang memperhatikan dan ramai sendiri. Interaksi tanya jawab dengan guru dalam proses pembelajaran masih jarang terjadi. Kurangnya rasa percaya diri dan masih terlihat malu ketika mengkomunikasikan hasil belajar mereka didepan kelas. Selain itu peserta didik juga belum mampu dalam menggunakan bahasa yang baik dan benar.

Melalui pembelajaran saintifik, peserta didik dituntut untuk mencari referensi dari berbagai sumber, baik sumber dari internet, buku, jurnal, dan lainnya. Peserta didik banyak yang merasa kesuitan dalam menyimpulkan referensi yag didapat. Selain itu dalam kenyataannya, peserta didik masih kesulitan menangkap maksud soal yang menggunakan HOTS, sehingga guru masih perlu melakukan cara mengajar didepan kelas (metode konvensional) untuk membuat siswa lebih bisa memahami.

Banyak sekali kendala yang dihadapi dalam pelaksanaan kurikulum 2013. Selain dalam proses mengkomunikasikan oleh peserta didik, pemahaman guru akan kurikulum 2013 juga menjadi kendala yang penting. Ditemukan dilapangan, ternyata tidak semua guru bisa menerima dengan mudah perubahan kurikulum. 


\section{KESIMPULAN DAN SARAN}

\section{A. Simpulan}

Dari analisis data hasil penelitian diperoleh kesimpulan sebagai berikut:

Pembelajaran matematika berbasis pendekatan saintifik sudah diterapkan dalam kegiatan pembelajaran, akan tetapi masih belum sepenuhnya guru menerapkan pendekatan tersebut di setiap pertemuan pembelajaraan. Menurut salah satu guru mengatakan bahwa kurkulum 2013 bagus dalam merangsang pemikiran siswa untuk dapat berpikir HOTS. Peserta didik lebih mandiri dalam mengerjakan soal karena sudah melakukan literasi terlebih dahulu sebelum pelajaran. Adapun kekurangan dari kurikulum 2013 ini adalah peserta didik masih kesulitan menangkap maksud soal yang menggunakan HOTS, sehingga guru masih perlu melakukan cara mengajar didepan kelas (metode konvensional) untuk membuat siswa lebih bisa memahami.

Hambatan yang dialami dalam kegiatan pembelajaran matematika berbasis pendekatan saintifik diantaranya:

1. Masih belum adanya perubahan tentang kurikulum lama. Guru masih menganggap metode ceramah dalam pelaksanaannya lebih efektif untuk kegiatan pembelajaran di kelas.

2. Diperlukan waktu yang lebih, untuk menerapkan materi kurikulum 2013 yang bertambah banyak.

3. Pada kegitan mengkomunikasikan, peserta didik masih kurang adanya rasa percaya diri dalam proses pembelajaran. Masih banyak yang kurang memperhatikan ketika ada peserta didik yang sedang mengkomunikasikan hasil didepan kelas.

\section{B. Saran}

Dari hasil penelitian dan kesimpulan, maka dapat diajukan saransaran sebagai berikut:

1. Bagi kepala sekolah henaknya melakukan monitoring dan pelatihna terhadap pelaksanan pembelajaran dn penilaian dalam kurikulum 2013 untuk meningkatkan kemamapuan guru dalam menerapkan kurikulum 2013.

2. Bagi guru, hendaknya terus belajar dan beradaptasi dengan kurikulum 2013 khususnya pada pelaksanaan pembelajaran dengan menggunakan pendekatan saintifik, menggunakan model pembelajaran yang bervariasi, dan penilaian, agar pelaksanaan kurikulum 2013 berjalan dengan baik dan maksimal.

3. Bagi peneliti selanjutnya untuk lebih memantapkan lagi hasil penelitin ini, untuk mengetahui faktor-faktor lain yang menghambat penerpan pembelajaran matematika berbasis pendekatan saintifik padaa kurikulum 2013 diperlukan penelitian yang sejenis. 


\section{DAFTAR RUJUKAN}

Arikunto, Suharsimi. 2013. Prosedur Penelitian, Suatu Pendekatan Praktik. Jakarta: Rineka Cipta.

Ernawati, 2014. Pengaruh Penerapan Pembelajaran Berbasis Pendekatan Scientifik Pd Mata Pelajaran Matemtika Kels VII di SMPN 1 Margahayu.

Daryanto, 2014. Pendekatan Pembelajaran Saintifik Kurikulum 2013. Yogykaarta: Gava Media.

Hosnan, M. 2014. Pendektan Saintifik Dan Konstektul Dlm Pembelajaran Abad 21. Bogor: Ghalia Indonesia.

Kurinasih, Imas. 2014. Sukses Mengimplementasikan Kurikulum 2013. Kata Pena

Moleong, Lexy J. 2012. Metodologi Penelitian Kualitatif. Bandung: Remaja Rosdakarya.

Sani, Ridwan Abdullah, 2014. Pembeljaran Saintifik Untuk Implementasi Kurikulum 2013. Jakarta: Bumi Aksara.

Sugiyono, 2014. Memahami Penelitian Kualitataif. Bandung: Alfbeta.

Sugiyono, 2012. Metode Penelitian Pendidikan. Bandung: Alfabetaa. 